\title{
A DEPICTION OF RADEN JOKO KAIMAN AS A SUPERHERO USING BARTHES' SEMIOTICS
}

\author{
Chusni Hadiati ${ }^{1 *}$; Nadia Gitya Yulianita ${ }^{2}$ \\ ${ }^{1,2}$ English Department, Faculty of Humanities, Jenderal Soedirman University \\ J1. Dr. Soeparno No. 60, Karangwangkal, Purwokerto, Jawa Tengah 53122, Indonesia \\ 'chusni.hadiati@unsoed.ac.id; ${ }^{2}$ nadiagityay@unsoed.ac.id
}

Received: $31^{\text {st }}$ March 2021/Revised: $24^{\text {th }}$ May 2021/Accepted: $31^{\text {st }}$ May 2021

How to Cite: Hadiati, C., \& Yulianita, N. G. (2021). A depiction of Raden Joko Kaiman as a superhero using Barthes' semiotics. Lingua Cultura, 15(1), 73-78. https://doi.org/10.21512/lc.v15i1.7267

\begin{abstract}
The research tried to reveal the denotative and connotative meaning of Raden Joko Kaiman in Banyumas culture. Historically, Banyumas regency was founded by Raden Joko Kaiman in 1582. As the founding father of Banyumas regency, Raden Joko Kaiman could be semiotically interpreted as a superhero in the context of Banyumas. Based on Barthes, anything could be a sign. Raden Joko Kaiman in Barthes'semiotic perspective could function as a sign since this figure could have both denotative and connotative meanings. Barthes' semiotic theory investigated the process of reading signs and their interpretation by different cultures or societies. Barthes considered sign as both signifier the physical form of the sign as people perceived it through their sense and signified the interpreted meaning. The research applied a qualitative method since it collected reliable data and information through reading, comparing, and analyzing text by relating them to Banyumas context. There are four denotative meanings carried by this sign, namely, the son of Raden Harya Banyak Sosro, the godson of Kiai Mranggi, the son-in-law of Adipati Wargautama, and being Adipati Mrapat. Connotatively, Raden Joko Kaiman is interpreted as courage, strong moral codes, tolerance towards pain, and a great sense of responsibility.
\end{abstract}

Keywords: Raden Joko Kaiman, superhero, Barthes'semiotics, Banyumas culture

\section{INTRODUCTION}

Banyumas is located in the southern part of Central Java. In the past, it was one out of seven Javanese culture systems (Koentjaraningrat, 1990). The remaining systems are Nagari Gung, Pesisir Wetan, Pesisir Kilen, Manca Nagari, and Bagelen. Banyumas area consists of four regencies, namely, Banyumas regency, Purbalingga regency, Banjarnegara regency, and Cilacap regency. Banyumas has a unique position in the skeleton of Javanese culture due to its anthropological and historical reason. Anthropologically, Banyumas lies between two immense cultures in Java, namely Javanese and Sundanese. The center of Javanese culture is in Surakarta and Jogjakarta, while Sundanese culture is in the western part of Java. Banyumas was situated between two big kingdoms, Majapahit and Padjajaran. The eastern part of Banyumas belonged to the westernmost region of the Majapahit kingdom, and the western part of Banyumas was in the easternmost region of the Padjajaran kingdom. These conditions, both anthropologically and historically, make Banyumas culture unique in Javanese culture so that Koentjaraningrat classified it as its own cultural area.

Banyumas regency was established by Raden Joko Kaiman after he divided the Wirasaba regency into four districts. Raden Joko Kaiman was the descendant of Raden Baribin (Sundanese culture), who eventually married one of Adipati Wargautama's daughters (Javanese culture) so that Raden Joko Kaiman himself was a portrait of acculturation among Sundanese and Javanese culture. Based on the historical notes, Raden Joko Kaiman as the founder of Banyumas regency, displayed the characteristics of a leader through what he had done in his life. He showed how to be a brave, responsible, tolerant, and moralistic leader. Figure 1 and 2 show the gate of Raden Joko Kaiman's tomb in Dawuhan village, Banyumas regency, Central Java.

The characteristics shown by Raden Joko Kaiman are in line with the characteristics of superheroes proposed by DeScioli \& Kurzban (2008). According to Bainbridge (2017), a superhero is a public figure with outstanding accomplishments. Through his 
lifespan, Raden Joko Kaiman can be considered as a sign which will be meaningful when people give them meaning. Since he is the founding father of Banyumas regency, Raden Joko Kaiman is the most central and essential sign in Banyumas culture as he is the first leader of Banyumas regency after it is parted from Wirasaba regency. To get an insightful meaning of Raden Joko Kaiman, semiotics, a study of sign can be applied as it has been widely used to depict the characteristics of a superhero, namely courage, strong moral codes, tolerance towards pain, and responsibility (Bainbridge, 2017; Hasanah \& Hidayat, 2020; MuñozGonzález, 2017).

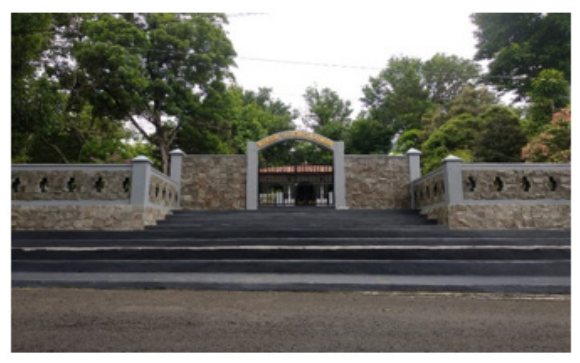

Figure 1 The Gate of the Raden Joko Kaiman's Tomb

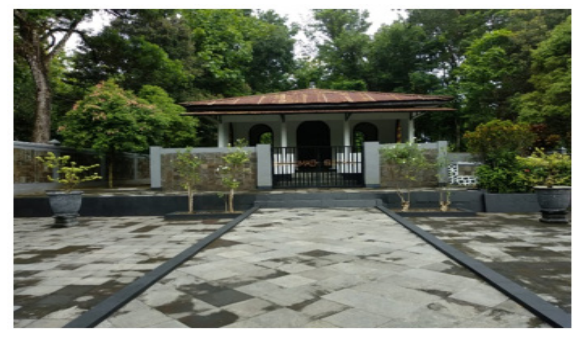

Figure 2 The Tomb of Raden Joko Kaiman in Dawuhan Village, Banyumas Regency, Central Java

Semiotics is the study of signs in human life that is not questionable (Balci \& Özgen, 2017; Hadiati, 2020; Pratiwi \& Amri, 2020). It indicates that anything that exists in human lives is seen as a sign, something that people have to give meaning or something that stands for something else. The notion of connotative, denotative, and myth to reveal the meaning of signs in human life has long been applied (Sulhan, 2016; Susanti \& Firdausi, 2019; Xu, 2018). However, none of these researches investigate the denotative and connotative meaning of a founding father of a certain area as a depiction of a superhero. Superhero's good traits can be revealed to enhance cultural value, which can be passed down from generation to generation. Thus, this research depicts the superhero characteristics of Raden Joko Kaiman by using Barthes' semiotics notion of denotation and connotation.

\section{METHODS}

The research applies a qualitative method since it simply analyzes words or images rather than numbers. The research does not give detailed statistics or mathematical equations; instead, it gives insightful elaboration of a social phenomenon of Raden Joko Kaiman. In brief, the research reveals the denotative and connotative meaning of Raden Joko Kaiman as a superhero in Banyumas context by using the semiotic approach proposed by Barthes. Banyumas is a region in Central Java with unique characteristics both in people and language (Hadiati, 2019). Library research is applied in the research, which means that researchers collect and gather the information related to the research subject through reading the related manuscripts. The researchers search articles, books, historical notes related to Raden Joko Kaiman and the history of the Banyumas regency. Simanjuntak (2009) has stated that the library research method is an appropriate research method by digging documentation, publication, government report, both the previous and the latest ones. The previous documents are used as the reference, while the newer documentation is used to show the latest information relating to the topic of discussion. The gathered information is carefully arranged and connected to Banyumas' historical and cultural background to depict Raden Joko Kaiman as a superhero in Banyumas context by revealing the concept of denotation and connotation proposed by Barthes. Context becomes influential in the discussion as it gives related information regarding the meaning of a sign (Oki, 2018). A superhero in one context may differ from other superheroes in other contexts (Saptanto \& Dewi, 2020).

\section{RESULTS AND DISCUSSIONS}

The result shows the denotation and connotation of Raden Joko Kaiman in the context of Banyumas culture. Raden Joko Kaiman as a sign can be denotatively and connotatively perceived (Table 1 ).

Table 1 Raden Kaiman as a Sign Denotatively and Connotatively

\begin{tabular}{|c|c|}
\hline \multicolumn{2}{|c|}{ Denotation } \\
\hline 1 & $\begin{array}{l}\text { Raden Joko Kaiman was the son of Raden Harya } \\
\text { Banyak Sosro. }\end{array}$ \\
\hline 2 & Raden Joko Kaiman was the god-son of Kiai Mranggi. \\
\hline 3 & $\begin{array}{l}\text { Raden Joko Kaiman was the son in-law of Adipati } \\
\text { Wargautama. }\end{array}$ \\
\hline 4 & Raden Joko Kaiman was known as Adipati Mrapat. \\
\hline \multicolumn{2}{|r|}{ Connotation } \\
\hline 1 & Courage \\
\hline 2 & Strong moral code \\
\hline 3 & Tolerance towards pain \\
\hline 4 & Great sense of responsibility \\
\hline
\end{tabular}

Semiotics tries to reveal the meaning of a sign that abundantly scatter in the world. Thus, those signs 
are meaningless until people give them meaning. A name is a simple sign that may have or have no meaning to certain people or cultures. The name Raden Joko Kaiman as the founding father of Banyumas regency has a heart-warming feeling to Banyumas culture (Purwokartun, 2020). Raden is an addressee term to salute a man with higher social status (Herusatoto, 2008). His life gives good examples to the Banyumas people. Raden Joko Kaiman can be said as a superhero for the Banyumas people.

The following discussion focuses on the denotative meaning of Raden Joko Kaiman. The first is that he is the son of Raden Harya Banyak Sosro. Raden Joko Kaiman or Raden Semangun or Bagus Mangun is actually the son of Raden Banyak Sosro (Herusatoto, 2008). It is in line with the record in Babad Banyumas translated by Purwokartun that states Raden Banyak Sosro died and left two children, a daughter and a son, the son is Bagus Mangun (Purwokartun, 2020). Raden Joko Kaiman is the son of Raden Harya Banyak Sosro and the grandson of Raden Harya Baribin. Raden Harya Baribin is the son in-law of Prabu Linggawastu, the king of Pakuan Parahiyangan kingdom. Prabu is an addressee term to salute a king in most of Java. From his family tree, it can be seen that Raden Joko Kaiman comes from a noble family.

The second denotative meaning of Raden Joko Kaiman is the fact that he is the god-son of Kiai Mranggi. When Raden Joko Kaiman was just a little boy, he was adopted by Kiai Mranggi. When his father passed away, Raden Joko Kaiman was appointed to be a shepherd. One day when he was herding the sheep, a spiritual ascetic approached him and led him to a strange and faraway place, near a river. When they arrived in that place, the spiritual ascetic disappeared after giving Raden Joko Kaiman some message. Raden Joko Kaiman ought to stay in that home and not to go anywhere until one day when he had to serve the Wirasaba regency. When Raden Joko Kaiman was alone at the bank of the river, Nyai Mranggi approached the river. She was delighted to find a boy and brought him home because she did not have one. She and her husband finally decided to adopt Raden Joko Kaiman as their son. Nyai Mranggi is the wife of Kiai Mranggi (Purwokartun, 2020). Nyai is an addressee term to salute a woman in a village. Kiai is an addressee term to salute a man with higher religious (Islam) rank in society. It is mentioned in Babad Banyumas that is in line with Herusatoto (2008), who explicitly stated that Raden Joko Kaiman was adopted by Kiai Mranggi, Raden Ayu Ngaisah's husband. Later on, they knew that Raden Joko Kaiman was actually their own nephew because Raden Ayu Ngaisah was, in fact, Raden Banyak Sosro's sister. Raden Ayu is an addressee term to salute a woman with higher social status in Javanese culture.

The fact that Raden Joko Kaiman is the sonin-law of Adipati Wargautama turns into the third denotative meaning. Raden Joko Kaiman becomes the son-in-law of Adipati Wargautama as he married the first daughter of Adipati Wargautama. When Raden
Joko Kaiman had grown up, he decided to serve the Wirasaba regency, so he had to leave his adoptive parents, Kiai and Nyai Mranggi. He then became a soldier in the Wirasaba regency. One night, when all soldiers were asleep, Adipati Wirasaba saw a light stroke into one of his soldiers who were asleep since he could not recognize the soldier, Adipati Wargautama, the head of Wirasaba regency, tore the soldier clothes. Adipati is an addressee term to salute the head of a regency. In the morning, Raden Joko Kaiman or Bagus Mangun was asked to face Adipati Wargautam. Raden Joko Kaiman was ordered to bring his father to the regency. Nyai Mranggi was afraid when Joko Kaiman arrived home and was informed that he had to bring his father to the regency. She was afraid that their son had made a mistake and his husband ought to pay the mistake. After Kiai Mranggi arrived in the regency, Adipati Wargautama said that he wanted Bagus Mangun or Raden Joko Kaiman to marry one of his daughters and finally Raden Joko Kaiman became the son in law of Adipati Wargautama (Purwokartun, 2020). Adipati Wargautama has five daughters, namely, Raden Ayu Kartimah, Ngabehi Wargawijaya, Ngabehi Wirakusuma, Ngabehi Wirayuda, and Raden Rara Sukartiyah. Raden Joko Kaiman married Raden Ayu Kartiman (Herusatoto, 2008). By marrying Raden Ayu Kartimah, Raden Joko Kaiman became the son in-law of Adipati Wargautama.

The fourth denotative meaning of Raden Joko Kaiman is that he is known as Adipati Mrapat. He gets his alias after he divided the Wirasaba regency into four areas. He is known as Adipati Mrapat for what he had done. Mrapat in Javanese means to divide into four parts. Papat in Javanese means four. Because of his bravery, Raden Joko Kaiman is then crowned as the head of the Wirasaba regency. Later on, he is known as Adipati Wargautama II. He has divided Wirasaba regency into four parts, namely, Wirasaba, Merden, Banjar Pertambakan, and Kejawar (Herusatoto, 2008; Purwokartun, 2020). Wirasaba is given to Ngabehi Wargawijaya which is then developed into Purbalingga regency nowadays, Merden area is given to Ngabehi Wirakusuma which is then developed into Cilacap regency now, Banjar Pertambakan is given to Ngabehi Wirayuda which is developed into Banjarnegara regency, and Kejawar is owned by Adipati Wargautama II which is developed into Banyumas regency.

The name of Raden Joko Kaiman has also displayed connotative meaning, which is in line with the superhero traits proposed by DeScioli \& Kurzban (2008). Connotation is resulted from the meaningmaking process of the sign and its historical context, cultural context, and belief. There are four connotative meanings of Raden Joko Kaiman that cope with superhero traits, namely, courage, strong moral codes, tolerance to pain, and a great sense of responsibility.

The second part sheds light on the connotative meaning of Raden Joko Kaiman. The connotative meanings of Raden Joko Kaiman also reflect his superhero traits. The first superhero trait depicted in the connotation meaning of Raden Joko Kaiman is 
courage. Courage is one of the superhero traits that has been investigated thoroughly (Armelia, 2019; Poplin, 2016). Raden Joko Kaiman is a courageous man who voluntarily faces Sultan Hadiwijaya in Pajang (Purwokartun, 2020). Adipati Wargautama is murdered by Pajang's soldiers based on Sultan Hadiwijaya's command. Later on, it is known that the command is mistaken and that Sultan Hadiwijaya feels sorry for his miss-command. He really wants to apologize, so that he asks one of Adipati Wargautama's children to come to the palace, but no one is brave enough to do so.

Adipati Wargautama is wrongly accused by Sultan Hadiwijaya as Sultan thinks that Adipati Wargautama sends not-virgin offerings to him, and consequently, Sultan thinks that Adipati Wargautama has lost his respect to him (Herusatoto, 2008). Sending virgin offerings to the Sultan is a kind of showing respect and loyalty. By being wrongly accused of sending non-virgin offerings, Adipati Wargautama is wrongly accused of being a traitor. Apparently, the leader of the Toyareka regency has slandered Adipati Wargautama by reporting to Sultan that Adipati Wargautama has sent a non-virgin offering to Sultan. It drives the Sultan mad, and he commands his soldiers to murder Adipati Wargautama. In the end, Adipati Wargautama is murdered for something he does not even realize. When Sultan Hadiwijaya realizes that he wrongly accuses and murders Adipati Wargautama, he wants to apologize. He invites Adipati Wargautama to come to the palace. No one, unfortunately, is brave enough to go to the palace except Raden Joko Kaiman. Before he leaves the Wirasaba regency, he has said that whatever happens, whether the Sultan would give him praise or punish him, no one in the family should not envy him (Purwokartun, 2020).

Raden Joko Kaiman, who is willing to head off to the palace, has shown how brave he is. He does not have any idea what will happen to his life, moreover after what has happened to his father-inlaw. He decides to go to the palace, he may lose his head, but he is not afraid. What he has done shows his courage. Courage is the ability to do something that may frighten or endanger one's life. Courage is one of the superhero characteristics proposed by DeScioli $\&$ Kurzban (2008). They have noted that courage means that superheroes have a strong ability to face fears. Courage is not a lack of fear. In general, it is the willingness to confront fear. Even it takes courage to face injustice, many people fear for their lives. When Raden Joko Kaiman finally decides to go to the palace, he may face injustice or dangerous situations that may harm his life, but he still does that. The courage shown by Raden Joko Kaiman has made him a superhero in Banyumas context since he is brave enough to go to the palace instead of the chaotic situation in Wirasaba after the murder of Adipati Wargautama because of the wrong accusation. The courage of Raden Joko Kaiman to head off to the palace despite the dangerous situation reflects a connotative meaning of Raden Joko Kaiman himself. It highlights that at the connotative level, meaning is resulted from the relation between signifier and signified in wide scope that includes belief, habits, framework, and ideology of a social formation.

Strong moral code is the second superhero trait owned by Raden Joko Kaiman. A strong moral code is one of the superhero traits that has been investigated so far by several scholars (Comerford, 2016; Picón del Campo, 2018). As a leader and not the descendant of Adipati Wargautama, Raden Joko Kaiman is willing to share his regency into four areas to be equally divided with his brothers and sisters-in-law. Thus, the second superheroes trait depicted by Raden Joko Kaiman is strong moral codes since he is willing to divide the Wirasaba regency into Wirasaba, Merden, Banjar Pertambakan, and Kejawar (Herusatoto, 2008; Purwokartun, 2020).

Having attended the invitation from Sultan Hadiwijaya, Raden Joko Kaiman is finally granted as the head of Wirasaba regency to replace his fatherin-law, Adipati Wargautama, who is murdered due to the wrong accusation. When Raden Joko Kaiman crowned as the head of Wirasaba, he is given the title as Adipati Wargautama II (Herusatoto, 2008). Raden Joko Kaiman has realized that he is only a son-in-law of Adipati Wargautama and has three brother-in-laws. Having been permitted by Sultan Hadiwijaya, Raden Joko Kaiman or Adipati Wargautama II has divided Wirasaba regency into four parts, i.e., Wirasaba, Merden, Banjar Pertambakan, and Kejawar. Wirasaba is given to his first brother-in-law, Ngabehi Wargawijaya, Merden is given to his second brother-in-law, Ngabehi Wirakusuma, Banjar Pertambakan is given to his youngest brother-in-law, Ngabehi Wirayuda, and Kejawar for himself. Wirasaba nowadays has developed into Purbalingga regency, Merden has settled as Cilacap regency, Banjar Pertambakan has established into Banjarnegara regency, and Kejawar has urbanized into Banyumas regency.

The magnanimity of Raden Joko Kaiman to divide Wirasaba into four regencies has shown his strong moral code. He realizes that he is not a son by the blood of Adipati Wargautama I, but still, when he is crowned as Adipati Wargautama II, he does not take all the glory for himself. If Raden Joko Kaiman is not a man of strong moral code, he may be reluctant to share his brother-in-laws the same glory. His willingness not to be selfish shows how he is a moralistic man, one of the traits of a superhero. Connotatively, the meaning of Raden Joko Kaiman as a superhero with a strong moral code is a resultant from the amalgamation of history, experience, and culture of the society. A strong moral code displayed by a superhero is supposed to be copied by the surroundings (Yogerst, 2017). Raden Joko Kaiman displays a strong moral code in Banyumas' context by sharing the glory with his brothers-in-law. His strong moral code proves that Raden Joko Kaiman is a superhero. A superhero should inspire others to do good deeds (Cochran, 2017).

The third superhero trait, which is also the third connotative meaning of Raden Joko Kaiman, is tolerance to pain. Tolerance to pain is a superhero trait that can be contextually applied (Krypton, 2018; 
Wibawa, 2016). This trait has also been displayed by Raden Joko Kaiman during his life. When he has decided to go to the Wirasaba regency and applied as a guard, he has to keep the safety of the regency. He sometimes keeps up all night. One night, it was his turn to rest, but he replaced another guard who could not commit the duty. When he fell asleep, a light struck his body, causing him pain. Adipati Wargautama, by accident, saw that thing when he went patrol that night. Since the night was too dark, Adipati Wargautama could not recognize his guard, so he tore the guard's clothes. The next morning, Adipati Wargautama finally found the guard and asked the guard to explain where he came from and his background. Adipati Wargautama knew that when a light stroke into a man, that man would be a leader one day. After Joko Kaiman explained himself, Adipati Wargautama asked him to bring his god-father to the palace. When Kiai Mranggi arrived at Wirasaba regency, Adipati Wargautama asked his permission to wed Joko Kaiman with his eldest daughter, Rara Kartimah (Herusatoto, 2008).

Having been struck by a light may harm a man's body; however, Raden Joko Kaiman could tolerate the pain. This means that he is not an ordinary man or that God has given him the strength to tolerate pain. In Javanese culture, when people are struck by lightning, and he or she still survived, he or she is believed to be special. Having seen that Joko Kaiman is still survived after being struck by lightning, Adipati Wargautama believes that Joko Kaiman would be a leader someday. This belief has lived in Javanese culture for ages.

The ability to tolerance towards pain is one of the characteristics of a superhero. It is supported by the cultural belief that people who are struck by lightning would be a leader someday. It results in the connotation meaning of Raden Joko Kaiman in Banyumas context. The ability to survive after being struck by light is a non-humanistic trait, probably only owned by a superhero (Cook \& Frey, 2017). In other words, this superhero characteristic is a manifestation of the connotative meaning of Raden Joko Kaiman.

The last characteristic of a superhero shown by Raden Joko Kaiman is an excellent sense of responsibility. As one trait of the superhero, a great sense of responsibility has been explored so far by Peña and Chen (2017) and Zarate (2019). Raden Joko Kaiman has displayed a great sense of responsibility in his life. When Adipati Wargautama was murdered because of a wrong accusation, Sultan Hadiwijaya asked one of the descendants of Adipati Wargautama to head off to the palace. However, no one was brave enough to answer the invitation. When Raden Joko Kaiman voluntarily answered the invitation, it shows that he had a great sense of responsibility. Nobody knew what would happen to Raden Joko Kaiman at that time when he headed off to the palace; they were terrified and thought that Sultan still felt furious and wanted to murder Raden Joko Kaiman as the sonin-law of Adipati Wargautama. Raden Joko Kaiman also did not have any idea as to what would happen to his life. All he thought was that he had to take the responsibility to head off to the palace after the death of his father-in-law. Before Raden Joko Kaiman and his wife headed off to the palace, he said to his brother and sisters-in-law that whatever happened to him and his wife, whether they would be murdered or got any glory from the Sultan, they ought to sincerely accept it. They all agreed upon it (Herusatoto, 2008; Purwokartun, 2020).

Raden Joko Kaiman, in fact, is given glory by the Sultan, and he is crowned as the head of Wirasaba regency, replacing his late father-in-law. Sultan considers Raden Joko Kaiman as a responsible son-inlaw who is brave enough to handle the consequence. His responsibility made Sultan grants him the position of a leader. Raden Joko Kaiman had done shows a great sense of responsibility which brought the connotative meaning of Raden Joko Kaiman in Banyumas context. A great sense of responsibility is one of the superhero traits because most superheroes are motivated by something extraordinary to ensure that other people around them are safe (DeScioli \& Kurzban, 2008). By taking the responsibility to head off to the palace replacing his late father-in-law, Raden Joko Kaiman shows a great sense of responsibility. It reveals the connotation of Raden Joko Kaiman as a sign in Banyumas' historical, cultural, and beliefs.

\section{CONCLUSIONS}

Raden Joko Kaiman as the founding father of Banyumas regency, can be seen as a sign. The embellishment of Raden Joko Kaiman as a sign in the semiotic approach has proven that the founders of the regency are meaningful as long as people give them meaning. The name Raden Joko Kaiman may mean nobody in a different cultural context. The denotative meaning of Raden Joko Kaiman has revealed his personal information; meanwhile, the connotative meaning has figured out his characteristics as a superhero in Banyumas culture. The research has portrayed the denotative meaning of Raden Joko Kaiman as well as his connotative meaning. The finding can be completed by other research so that further research is highly appreciated, particularly by utilizing different semiotics approaches to get a more comprehensive understanding of the depiction of Raden Joko Kaiman in Banyumas context.

\section{ACKNOWLEDGEMENTS}

We would like to express our gratitude to Jenderal Soedirman research and community service institution for fully funded this research under the scheme Riset Institusi fiscal year 2020, Grant No. Kept. 119/UN23.18/PT.01.05/2020 entitled Simbolisme dalam Kebudayaan Banyumas: Sebuah Kajian Semiotika Budaya. 


\section{REFERENCES}

Armelia, L. (2019). Critical discourse analysis on Spiderman. Syntax Literate: Jurnal Ilmiah Indonesia, 4(9), 43-49. https://dx.doi.org/10.36418/syntax-literate. v4i9.708.

Bainbridge, J. (2017). Beyond the law: What is so "super" about superheroes and supervillains? International Journal for the Semiotics of Law, 30(3), 367-388. https://doi.org/10.1007/s11196-017-9514-0.

Balci, V., \& Özgen, C. (2017). What sports advertising tell to us? Semiotic analysis. Journal of Education and Training Studies, 5(6), 24-32. https://doi. org/10.11114/jets.v5i6.2387.

Cochran, D. L. (2017). Canvases of representation: Addressing the cultural politics of black male superhero identity in graphic narratives. Illinois: Illinois State University. Retrieved from https:// ir.library.illinoisstate.edu/etd/731.

Comerford, C. (2016). Ambiguous heroism: Anti-heroes and the pharmakon of justice. Interactive Media E-Journal, 11, 1-13.

Cook, M. P., \& Frey, R. (2017). Using superheroes to visually and critically analyze comics, stereotypes, and society. SANE Journal: Sequential Art Narrative in Education, 2(2), 1-33.

DeScioli, P., \& Kurzban, P. (2008). Cracking the superhero's most code (The Psycho; R. Rosenberg, Ed.). Dallas: TX BenBella Books.

Hadiati, C. (2019). Felicity conditions of the speech acts in Banyumasan daily conversation. Theory and Practice in Language Studies, 9(6), 700-705. https:// doi.org/10.17507/tpls.0906.13.

Hadiati, C. (2020). Foreign language lexicons used in Indonesian housing names: A Peircean semiotic overview of Indonesian housing names. Celt: $A$ Journal of Culture, English Language Teaching \& Literature, 20(2), 322-333. https://doi.org/10.24167/ celt.v20i2.2789.

Hasanah, N., \& Hidayat, D. N. (2020). A semiotic analysis of political cartoons on the first 100 days of Anies Baswedan government. EduLite: Journal of English Education, Literature and Culture, 5(2), 322-333. https://doi.org/10.30659/e.5.2.322-333.

Herusatoto, B. (2008). Banyumas: Sejarah, budaya, bahasa, dan watak. Yogyakarta: LKiS.

Koentjaraningrat. (1990). Pengantar ilmu antropologi. Jakarta: Djambatan.

Krypton, A. (2018). The form of conflict toward power authority on superhero graphic novel: Semiotic analysis on The Watchmen graphic novel. KnE Social Sciences, 3(11), 746-755. https://doi.org/10.18502/ kss.v3i11.2803.

Muñoz-González, R. (2017). Masked thinkers? Politics and ideology in the contemporary superhero film. Kome, 5(1), 65-79. https://doi.org/10.17646/ KOME.2017.14.
Oki, E. (2018). The Polish superheroes have arrived! On the popularity of superhero stories and adaptations. European Journal of American Studies, 13(3), 1-12. https://doi.org/10.4000/ejas.13678.

Peña, J., \& Chen, M. (2017). With great power comes great responsibility: Superhero primes and expansive poses influence prosocial behavior after a motioncontrolled game task. Computers in Human Behavior, 7, 378-385. https://doi.org/10.1016/j. chb.2017.07.039.

Picón del Campo, N. (2018). Wolverine and American mythology: The ultimate anti-hero. JACLR: Journal of Artistic Creation and Literary Research, 6(1), 2337.

Poplin, J. (2016). New heroes, ideological shifts and Chinese visual culture. Interactive Media E-Journal, 11, 1-14.

Pratiwi, A., \& Amri, U. (2020). The analysis of linguistic signs and symbol in celebrity fragrance advertisements. IMLAH: Islamic Manuscript of Linguistics and Humanity, 2(1), 15-26.

Purwokartun, N. (2020). Babad Banyumas: Serat Babad Banyumas Mertadiredjan. Banyumas: Bale Pustaka Penerbitan.

Saptanto, D. D., \& Dewi, M. K. (2020). Gundala and Gatotkaca in the concept of modern Indonesian superheroes: Comparative analysis of the Indonesian and American superheroes. EduLite: Journal of English Education, Literature and Culture, 5(1), 136-147. https://doi.org/10.30659/e.5.1.136-147.

Simanjuntak, R. R. (2009). Bahasa Indonesia: Policy, implementation, and planning. Lingua Cultura, 3(1), 11-19. https://doi.org/10.21512/lc.v3i1.327.

Sulhan, I. (2016). Internet meme analysis: Interpretative semiotic analysis on the "Scumbag Steve". Communicare: Journal of Communication Studies, 3(1), 21-36.

Susanti, A., \& Firdausi, N. A. (2019). Representasi brand Islami dalam produk kopi (Analisis semiotika Roland Barthes pada brand produk kopi). Mediakom, 3(1), 53-67. https://doi.org/10.32528/mdk.v3i1.2411.

Wibawa, S. (2016). Children's heroism in Indonesian cinema: The representation of child. Interactive Media E-Journal, 11, 1-15.

Xu, Y. (2018). Barthes's semiotic theory and the TCSL classroom. Chinese Semiotic Studies, 14(2), 193227. https://doi.org/10.1515/css-2018-0013.

Yogerst, C. (2017). Superhero films: A fascist national complex or exemplars of moral virtue? Journal of Religion and Film, 21(1), 1-34.

Zarate, T. R. (2019). Utilizing visual rhetoric: A new approach to comics, superheroes, and red suns. San Bernardino: California State University. 